\title{
France joins Italy in mouse gene store bid
}

Rome. Mario Capecchi, an Italian-born geneticist who has played a major role in the development of knock-out gene technology - a technique by which animals are genetically engineered to contain a non-functioning copy of a specified gene - is to join the staff of a new mouse genetics centre being set up by the Italian government at Monterotondo near Rome. Capecchi is currently working in the United States.

The appointment will strengthen the centre's bid to host a planned European mouse mutant repository, a collection of mutant strains of mice, kept either alive or as frozen embryos, which will be made available on request to research scientists (see Nature 372, 305; 1995).

Given the increasing importance of such mice in research, the European Commission (EC) has set aside special funds in its fourth Framework programme for mutant repositories. Research organizations in Italy, France, Germany and the United Kingdom are backing an application to house the mouse gene repository at Monterotondo.

Despite a general freeze on public appointments, Italy agreed last week to release money for Capecchi's appointment from a scheme set up by the former research minister, Antonio Ruberti, to bring leading scientists working abroad, back to Italy.

Capecchi's role has not yet been precisely defined. But it will involve an overseeing role that will include coordinating the interaction between the international and national activities of the centre.

Capecchi, who is 57, will retain his post at the Howard Hughes Medical Center in Utah. He says that at first he will simply be giving advice on setting up the centre. Later, however, "there is a good possibility of going beyond this". He says that he will probably spend more time in Italy once the centre is operating, and looks forward to doing what he can "to help continue Italy's tradition of producing good scientists". Although Italy remains strong in physics, its expertise in biology has declined over the past two decades, something that it is keen to correct.

Attracting Capecchi to the centre adds weight to its application to host the EC's main mouse mutant repository, as a strong research environment is considered essential. The Consiglio Nazionale della Ricerche (CNR) has already agreed to move its own Rome-based molecular biology research groups of about 100 staff into the Monterotondo laboratories, which were donated by the Italian ENI oil company, In addition, four regional groups of the European Molecular Biology Laboratory (EMBL) will be established there by the end of the year.

According to Enrico Garaci, the head of the CNR, the combination of these activities means that Italy will have a strong research environment at Monterotondo to back its application to Brussels. The CNR has already agreed to finance the expansion of the genetic repository facilities if this becomes necessary after a few years.

Consensus between the CNR, Germany's Max Planck Society and France's Centre National de la Recherche Scientifique (CNRS), which last year set up a joint search committee to identify a suitable site for the proposed mouse genetics repository, has not been achieved without a struggle.

The committee wanted a main laboratory with a series of "networking nodes" in other countries to provide additional input or services to back up the main facility. The nature and relative importance of the nodes was initially a point of heated argument between the organizations.

France, which recently complained that Italy would win the bid for the host site because of no competition (see Nature 373, $276 ; 1995)$, was particularly keen for its own CNRS animal breeding laboratory in Orléans to play a significant role.

The French view has now prevailed. In the application, submitted before the deadline this week, the CNRS laboratory would be the main supporting laboratory - or 'node' — which would duplicate the frozen embryos stored at Monterotondo. "For security reasons, [the CNRS] thought it would be good to have at least two places where frozen embryos are kept," says François Galibert of CNRS.

The new plan is also of direct benefit to France. Two years ago, CNRS decided to expand its animal facilities in Orleans to act as a national mouse mutant repository. The laboratories look after around 150 live strains of transgenic and knock-out rodents, and around 250 strains as frozen embryos. But its small research facility will be joined later this year by a larger research group transferred from Paris, and more groups will be encouraged to move there later, according to Galibert.

If the EC application covering a main laboratory at Monterotondo and a main node at Orléans - costing just under ECU6 million (US \$4.6 million) over a four-year period - is successful, additional national nodes will be added later. A second phase application to the EU, that is likely to include a bid for another 'node' from Britain's Medical Research Council, will be submitted by the end of the year.

\section{UK puts science in the limelight}

London. Sunday morning at London's Euston railway station. All is quiet except for the arrival (left) of a 15-foot replica of the DNA double helix, not part of this year's charity fund-raising extravaganza "Comic Relief", but of another deserving cause: promoting British science.

The model, designed by Alan Ward, forms the centrepiece of an exhibition about modern genetics organized by the Wellcome Trust and the Medical Research Council, one of over 3,000 events celebrating the second UK National Science Week.

Money has been provided for individual events by a mixture of private sponsors including British Gas and IBM, who sponsored the opening ceremonies, grants worth $£ 95,000$ (US\$ $150,500)$ from the Committee on the Public Understanding of Science.

As a reward for the $£ 50,000$ grant from the Office of Science and Technology, John Horam, the junior science minister, received a guided tour of the microbiology of brewing courtesy of the 'yeast beast' - "a giant flocculating head of beer with a demented look on his face" - at the Bass [Brewers']

\section{Museum in Derbyshire.}

This year has seen an attempt to give Science Week a more serious flavour with press briefings being held by all the research councils, in addition to public events. The Health and Safety Executive used the week as a platform to launch its former Research and Laboratory Services Division as a new government agency, the Health and Safety Laboratory.

David Hunt, the science minister, gave a keynote address on 17 March. He told his audience the date was a particularly appropriate one on which to open the Science Week as it marked the anniversary of a major (and patented) British invention: the elastic band. 